\title{
PENGARUH AKULTURASI BUDAYA TERHADAP DUALISME SISTEM EKONOMI MASYARAKAT KAMPUNG TUA DI KECAMATAN ABUNG TIMUR, KABUPATEN LAMPUNG UTARA
}

\section{THE EFFECT ON CULTURE ACCULTURATION TOWARD THE DUALISM OF KAMPUNG TUA COMMUNITY ECONOMIC SYSTEM IN EASTERN DISTRICT OF ABUNG, NORTH DISTRICT LAMPUNG}

\author{
${ }^{1}$ Lia Nuralia $\&{ }^{2} \operatorname{Iim}$ Imadudin \\ ${ }^{1}$ Balai Arkeologi Jawa Barat \\ ${ }^{1} J 1$. Raya Cinunuk Km 17, Cileunyi, Bandung 40623 \\ ${ }^{2}$ Balai Pelestarian Nilai Budaya Jawa Barat \\ ${ }^{2} J l n$. Cinambo No.136 Ujungberung-Bandung 42094 \\ e-mail: liabalar@yahoo.com \\ imadudin75@gmail.com
}

\begin{abstract}
Abstrak
Tulisan ini bertujuan mengungkap sejarah dan budaya masyarakat adat Kampung Tua di Lampung. Sumber tulisan merupakan hasil penelitian dengan menggunakan metode survey, dan teknik pengumpulan data melalui studi literatur, observasi langsung, dan wawancara. Kajian dilakukan dengan menerapkan konsep-konsep ilmu sosial, yaitu konsep akulturasi budaya dan sistem ekonomi dualistis (tradisional dan modern), menghasilkan sistem nilai yang unik dan menjadi pedoman dalam kehidupan sehari-hari masyarakat Kampung Tua. Akulturasi budaya tampak pada gaya bangunan rumah tinggal dan dua sistem adat lama (pepadun dan sebatin), beserta benda-benda upacara adat Begawi, sedangkan sistem ekonomi dualistis dengan keberadaan umbulan dan kuwayan. Tata nilai yang berlangsung mengalami perubahan dalam berbagai segi kehidupan, tetapi tetap berpedoman pada nilai-nilai kehidupan lama yang masih bertahan sampai sekarang. Perekonomian tradisional di wilayah umbulan dan kuwayan tergantikan dengan masuknya perekonomian modern.
\end{abstract}

Kata kunci: akulturasi budaya, dualisme ekonomi, Kampung Tua.

\begin{abstract}
This paper aims to reveal the history and culture of indigenous people in Kampung Tua of Lampung. The writing source is the result of research by using survey method, and the data is collected through the study of literature, direct observation, and interviews. The study is conducted by applying the concepts of social sciences, acculturation, and dualistic economic systems (traditional and modern), it produces a unique value system and guide people's daily lives of Kampung Tua. Acculturation can be seen from the style of houses and two old custom system (pepadun and sebatin), along with the customary ceremonial objects of Begawi. Meanwhile, the dualistic economic system can be seen from the existence of umbulan and kuwayan. The lasting value changes in various aspects of life, but remain guided by the values of the old life until now. Traditional economy in the region of kuwayan and umbulan is replaced by the entry of modern economy.
\end{abstract}

Keywords: acculturation, economic dualism, Kampung Tua. 


\section{A. PENDAhuluan}

Sebagai salah satu bentuk proses sosial, akulturasi erat kaitannya dengan pertemuan dua kebudayaan atau lebih. Akibat pertemuan tersebut, kedua belah pihak saling memengaruhi. Pada akhirnya kebudayaan mereka mengalami perubahan bentuk. Para antropolog sejak lama menunjukkan minatnya akan peristiwa terjadinya proses akulturasi, dengan tujuan mengetahui dan memahami sejauh mana dari proses tersebut dapat menyebabkan terjadinya perubahan baik perubahan sosial maupun budaya.

Para ahli memiliki beragam pendapat tentang pengertian akulturasi. Definisi klasik mengenai akulturasi dikemukakan Redfield, Linton, dan Herskovits (1936)"acculturation comprehends these phenomena which result when groups of individuals having different cultures come into continous firt-hand contact, with subsequent changes in the original cultural pattens of either or both groups" (Akulturasi meliputi fenomena yang timbul sebagai hasil, jika kelompokkelompok manusia yang mempunyai kebudayaan yang berbeda-beda bertemu, dan mengadakan kontak secara terus menerus, yang kemudian menimbulkan perubahan dalam pola kebudayaan yang original dari salah satu kelompok atau kedua-duanya) (Berry and Sam, 1997: 293).

Kajian pertemuan dua kebudayaan atau lebih bukan hanya berlaku dari kalangan tribe dari suatu ras tertentu, melainkan lebih menekankan pada suatu kelompok kemasyarakatan (social groups). Bahkan, dalam perkembangannya akulturasi memiliki makna yang lebih fleksibel, "the importing of culture by one people to another (Poerwanto, 1999: 29).

Dalam kajian akulturasi terdapat empat masalah utama, yakni (1) unsurunsur kebudayaan asing apakah yang mudah diterima atau sukar diterima; (2) unsur-unsur kebudayaan apakah yang mudah diganti atau diubah oleh kebudayaan asing; (3) individu-individu manakah yang cepat menerima unsurunsur kebudayaan asing, atau sebaliknya; (4) berbagai ketegangan dan krisis sosial sebagai akibat terjadinya akulturasi (Purwanto, 2000:186).

Proses akulturasi, sebagaimana dikemukakan Koentjaraningrat (1958), dapat dikaji menggunakan pendekatan lima prinsip, yaitu: (1) Principle of integration (prinsip integrasi) yaitu suatu proses di mana unsur-unsur yang saling berbeda dari kebudayaan mencapai keselarasan dalam kehidupan masyarakat; (2) Principle of function (prinsip fungsi), yaitu unsurunsur yang tidak akan mudah hilang, apabila unsur-unsur itu mempunyai fungsi yang penting dalam masyarakat; (3) Principle of early learning, sebagai prinsip yang terpenting dalam proses akulturasi, yang menyatakan bahwa unsur-unsur kebudayaan yang dipelajari paling dahulu, pada saat si individu pendukung kebudayaan masih kecil, akan paling sukar diganti oleh unsur kebudayaan asing; (4) Principle of utility, yaitu suatu unsur baru yang mudah diterima, bila unsur itu mempunyai guna yang besar bagi masyarakat; (5) Principle of concretness atau prinsip sifat konkret yaitu unsur-unsur konkret lebih mudah hilang diganti dengan unsur-unsur asing, terutama unsur-unsur kebudayaan jasmani, benda, alat-alat dan sebagainya.

Lampung memiliki pengalaman panjang dalam proses akulturasi. Heterogenitas Lampung memiliki dasar historis interaksi ulun Lampung (Orang Lampung atau Etnis Lampung) dengan masyarakat luar yang diperkirakan terjadi sejak beberapa abad yang lalu, antara lain dengan Cina, Banten, Bugis, dan Jawa baik melalui program kolonisasi maupun transmigrasi. Kemudian, interaksi yang berlangsung semakin ekstensif dengan masuknya kolonialisme dan kolonisasi ke bumi Lampung. Sejarah kontak ulun Lampung dengan etnis atau bangsa lain yang berlangsung selama ratusan tahun membuat mereka lebih terbuka dan identitasnya semakin cair. Komposisi 
penduduk berdasarkan suku bangsa di tahun 2000-an adalah Jawa sebesar $61,88 \%$, Lampung sebesar $11,92 \%$, Sunda (termasuk Banten) sebesar 11,27\%, Semendo dan Palembang sebesar 3,55\%, dan suku bangsa lainnya (Bengkulu, Batak, Bugis, Minang dan lain-lain) sebesar 11,35\% (Irianto dan Margaretha, 2011: 141). Interaksi ulun Lampung dengan etnik lain cenderung mengalami etnifikasi yaitu proses pemarginalan penduduk setempat di tanah kelahirannya yang membuat mereka tidak berkuasa atas lahan tersebut. Para migrannya telah membuat etnis lokal menjadi minoritas di daerah sendiri yang secara simbolik merupakan tanah tumpah darah (Irianto dan Margaretha, 2011: 141).

Masalah interaksi antarbudaya di Lampung dipandang sebagai isu yang cukup mengkhawatirkan. Beberapa konflik yang terjadi belakangan ini dipandang sebagai kegagalan akulturasi antaretnik di Lampung. Penelitian Humaedi (2014), misalnya, melihat intensitas konflik yang terjadi di Lampung sebagai kegagalan akulturasi budaya antara etnis pendatang dengan Lampung yang dimulai prosesnya dari ketiadaan ruang sosial bersama.

Dalam skala mikro, agaknya perlu satu penelitian yang lebih khusus tentang bagaimana akulturasi antarbudaya terjadi di wilayah Lampung. Tujuannya adalah bagaimana akulturasi harus dikelola sehingga dapat menjadi resolusi konflik yang memadai. Keragaman merupakan anugerah bagi keindonesiaan, namun berpotensi mengancam kehidupan berbangsa, khususnya kebijakan pembangunan yang terkait dengan pengelolaan kebudayaan.

Penelitian ini mengambil lokus di Kampung Tua Empat Serangkai, Kecamatan Abung Timur, Kabupaten Lampung Utara, Provinsi Lampung. Kampung ini diperkirakan sudah ada jauh sebelum kolonialisme Belanda masuk dan memengaruhi sendi-sendi kehidupan masyarakatnya. Mereka bermukim dan menjalankan rutinitas adat istiadat sesuai dengan budaya asli mereka.
Kampung Tua terbagi ke dalam 4 bagian wilayah kampung sesuai dengan marga penduduk asli, sehingga sering disebut Kampung Tua Empat Serangkai, yaitu: (1) Bumi Agung Marga, (2) Pungguk Lama, (3) Gedung Nyapah, dan (4) Penagan Ratu (Nuralia, 2014: 135).

Keempat marga memiliki kesamaan dalam adat dan meyakini berasal dari satu keturunan. Pada awalnya setiap marga bertempat tinggal mengelompok, sesuai marganya dan dipimpin oleh ketua adat.

Ketika Belanda menginjakkan kakinya di bumi Ruwa Jurai sekitar abad ke-19, masyarakat Kampung Tua tetap eksis dengan budayanya, tetapi tidak lepas dari pengaruh unsur-unsur budaya Barat yang masuk melalui kolonialisme Belanda, dan menjadi bagian dari budaya mereka di kemudian hari. Pencampuran dua budaya, Timur dan Barat, tidak dapat dihindari. Budaya Barat (asing) yang dibawa Belanda adalah budaya luar yang memengaruhi budaya Timur (asli) penduduk Kampung Tua.

Proses akulturasi di Kampung Tua terjadi pada budaya materi dan nonmateri. Akulturasi dari segi arsitektur adalah proses akulturasi pada budaya materi. Bangunan rumah tua yang mengalami sedikit perubahan. Pada budaya nonmateri tampak dalam upacara kenaikan takhta Begawi Sutan. Ada dua sistem adat, yaitu pepadun dan sebatin. Adat sebatin memilih ketua adat secara genealogis dan tidak bisa digantikan orang lain. Adat pepadun lebih demokratis, siapa pun bisa menempati tahta ketua adat (Sutan Pusetes, 1973).

Budaya Barat yang dibawa Belanda memengaruhi upacara adat tersebut, tetapi berada pada tataran permukaan.Substansi adat tetap berjalan sesuai aslinya. Keadaan tersebut menjadi daya tarik tersendiri sebagai enclave budaya khas, budaya asli Kampung Tua yang masih bertahan sampai sekarang.

Fenomena menarik lain adalah keberadaan umbulan dan lokasi kuwayan. Sebagai wilayah kantong perekonomian 
penduduk setempat secara bersama, umbulan menerapkan sistem ekonomi tradisional. Demikian juga lokasi kuwayan di tanah landai di tepi sungai, menjadi tempat penambatan perahu yang membawa barang-barang dagangan dari dalam dan luar kampung. Telah terjadi perdagangan antar kampung dengan sistem barter.

Sistem barter adalah salah satu cara distribusi barang-barang pada masyarakat tradisional. Cara distribusi tersebut sangat berpengaruh terhadap perkembangan sosial ekonomi suatu masyarakat. Ada tiga sistem distribusi, yaitu: (1) natural/perekonomian barter, (2) perekonomian uang, dan (3) perekonomian kredit. $^{1}$

Keberadaan umbulan dan bekas lokasi kuwayan menyebabkan terjadinya sistem ekonomi dualistis pada masyarakat Kampung Tua. Sistem ekonomi dualistis pada zaman Hindia Belanda hampir terjadi di seluruh Indonesia, terutama wilayahwilayah yang membuka lahan perkebunanperkebunan besar (Nuralia, 2016: 182 183). Menurut J.H. Boeke (1983), seorang ahli ilmu ekonomi timur, sistem ekonomi dualistis adalah berjalannya dua sistem ekonomi yang berlawanan sifatnya, dalam satu masa dan wilayah yang sama.

Sistem ekonomi dualistis bisa juga disebut sistem ekonomi campuran. Sistem ekonomi yang berusaha mengurangi kelemahan-kelemahan sistem ekonomi terpusat dan sistem ekonomi pasar. Dalam sistem ini pemerintah bekerja sama dengan pihak swasta dalam menjalankan kegiatan perekonomian (Kardiman, 2006 : 80).

Akulturasi budaya dan sistem ekonomi dualistis masyarakat Kampung Tua menjadi permasalahan pokok dalam tulisan ini. Dengan demikian, tujuan kajian ini adalah mengungkap pengaruh

\footnotetext{
${ }^{1}$ Bruno Hildebrand, Die National Ekonomie der gegenwart und Zukunfit (1848), http://www.encyclopedia. com/socialsciences/applied-and-social-sciencesmagazines/hilde brand-bruno, diakses 29 Desember 2016.
}

akulturasi budaya terhadap sistem ekonomi dualistis pada masyarakat Kampung Tua.

\section{B. METODE PENELITIAN}

Metode penelitian yang digunakan adalah metode penelitian survey dengan teknik pengumpulan data melalui studi literatur, observasi langsung, dan wawancara. Observasi dilakukan terjun langsung ke lapangan, mencari dan menemukan beberapa objek sejarah dan budaya (data fisik). Pada saat observasi dilakukan pengukuran, pemotretan, pencarian titik koordinat, penggambaran, serta pencatatan dan deskripsi. Datafisik dilengkapi dengan informasi kesejarahan (data nonfisik) melalui wawancara terbuka kepada beberapa orang ketua adat marga dan penduduk Kampung Tua. Sementara itu, studi literatur dilakukan melalui bukubuku, artikel dalam jurnal ilmiah, dan laporan hasil penelitian, serta internet.

\section{HASIL DAN BAHASAN \\ 1. Penduduk Asli Kampung Tua ${ }^{2}$}

Penduduk asli Kampung Tua Empat Serangkai merupakan keturunan Minak Semelasem dan Putri Minak Surakarta. Mereka melahirkan anak bernama Minak Paduka, yang menjadi nenek moyang penduduk asli Bumi Marga. Kemudian tiga bersaudara keturunan Minak Gusti Selangu atau Minak Pulan Brajo Tua dari Cangok Gacak, yaitu Minak Pulan Brajo, Minak Pengantin, dan tidak diketahui namanya, menurunkan penduduk asli Pungguk Lama, Penagan Ratu, dan Gedung Nyapah. Minak Gusti Selangu adalah adik dari Minak Semelasem. Kampung Penagan Ratu secara geografis terletak pada koordinat 044'15,6" LS dan 10446'24,0" BT; berjarak sekitar $12 \mathrm{~km}$ dari ibu kota kabupaten, yaitu Kotabumi; memiliki batas-batas wilayah desa, yaitu (1) sebelah

\footnotetext{
${ }^{2}$ Hasil wawancara dengan beberapa tokoh adat Kampung Tua (2012), ditambah data tertulis pada Monografi Kecamatan Abung Timur, serta hasil observasi langsung di lapangan.
} 
utara dengan Tulung Mas dan Gedung Jaya, (2) sebelah selatan dengan Tulung Udim, Senuli Raya, dan Gedung Harapan (3) sebelah barat dengan Gedung Nyapah, Pungguk Lama, dan Bumi Agung Marga, (4) sebelah timur dengan Surakarta dan Sumber Agung.
Kampung Bumi Agung Marga secara geografis terletak pada koordinat $4^{\circ} 45^{\prime} 15.5^{\prime \prime}$ LS dan $104^{\circ} 56^{\prime} 25.2^{\prime \prime}$ BT dengan ketinggian 55 meter di atas permukaan laut. Kampung ini memiliki batas-batas wilayah desa sebagai berikut: (1) sebelah utara dengan Pungguk Lama

Peta 1. Keletakan Wilayah Kampung Tua Empat Serangkai dalam Peta Topografi dan Peta Wilayah Kabupaten Lampung Utara, Provinsi Lampung

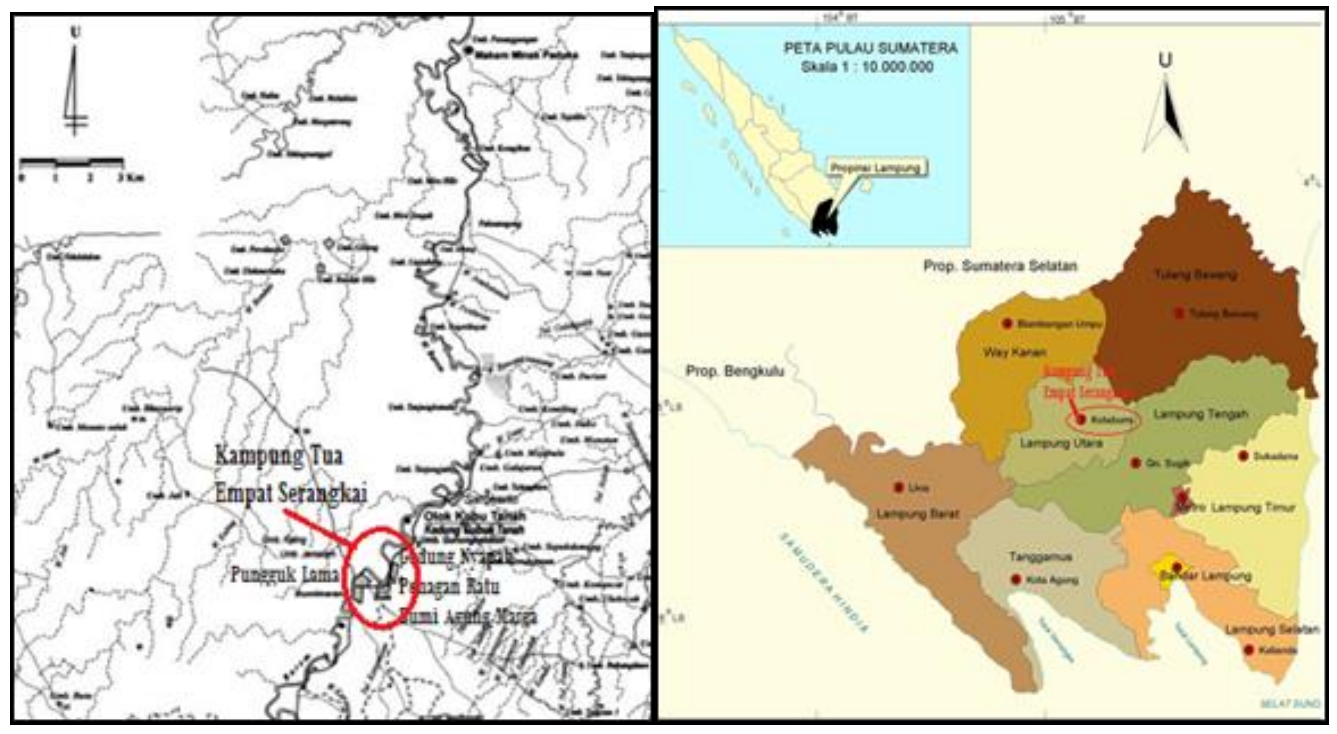

Sumber: Tim Penyusun, 2012.

Penduduk asli Kampung Penagan Ratu berasal dari suku bangsa Melayu, Lampung Benggali, Lampung Sungkai, Bugis, Cina, dan Jawa. Mereka datang ke Kotabumi Ilir, terus ke Bumi Agung Bawang Sepulau, dan berlanjut ke Bumi Agung Marga. Kemudian masyarakat Penagan Ratu, Gedung Nyapah, dan Pungguk Lama berasal dari bapak yang sama berlainan ibu. Nenek moyang mereka berasal dari Tali Tunggal bermukim di Bawang Tuba (1040), menurunkan 3 orang anak (Roh Tunggal, Sang Bina Tunggal, danSerapu Bisa), yang bermukim di Way Batang (1070-1130). Selanjutnya ada 3 keturunan bermukim di Gunung Kerinci Jambi, yaitu Biso Pu Gajah, Putra Guru, dan Sang Balai Puang (1140-1220). Ada juga 3 keturunan yang bermukim di Rejag Brak, yaitu Apu So Tubo, Apu Cangeh, dan Apu Serunting (1220-1340). dan Peraduan Waras, (2) sebelah selatan dengan Sumber Harum, Candi Mas, dan Kembang Tanjung, (3) sebelah barat dengan Margo Rejo dan Papan Rejo, (4) sebelah timur dengan Peraduan Waras dan Semuli Jaya.

Pendiri kampung Bumi Agung Marga adalah Minak Peduko di Bawang Sepulau, salah satu dari Minak Trio Deso. Dua lainnya Minak Penatih Tuha dan Minak Semelasem, keturunan Abung Siwo Mego ${ }^{3}$ dari nenek moyang Datuk Di Puncak.Lokasi Bawang Sepulau sekarang berupa dusun, sedangkan dahulu daerah induk tempat tinggal Nunyai gelar Minak Trio Deso yang menurunkan tokoh Abung Siwo Mego. Abung Sewo Mego terdiri dari Marga Nunyai Gelar Minak Trio Deso, Marga Unyi, Marga Subing, Marga

\footnotetext{
${ }^{3}$ Tokoh Abung Siwo Mego, salah satu tokoh adat Pepadun, di samping Pubian Telu Suku, Way Kanan, Sungkai dan Tulangbawang.
} 
Peta 2. Denah Wilayah Kampung Tua Empat Serangkai

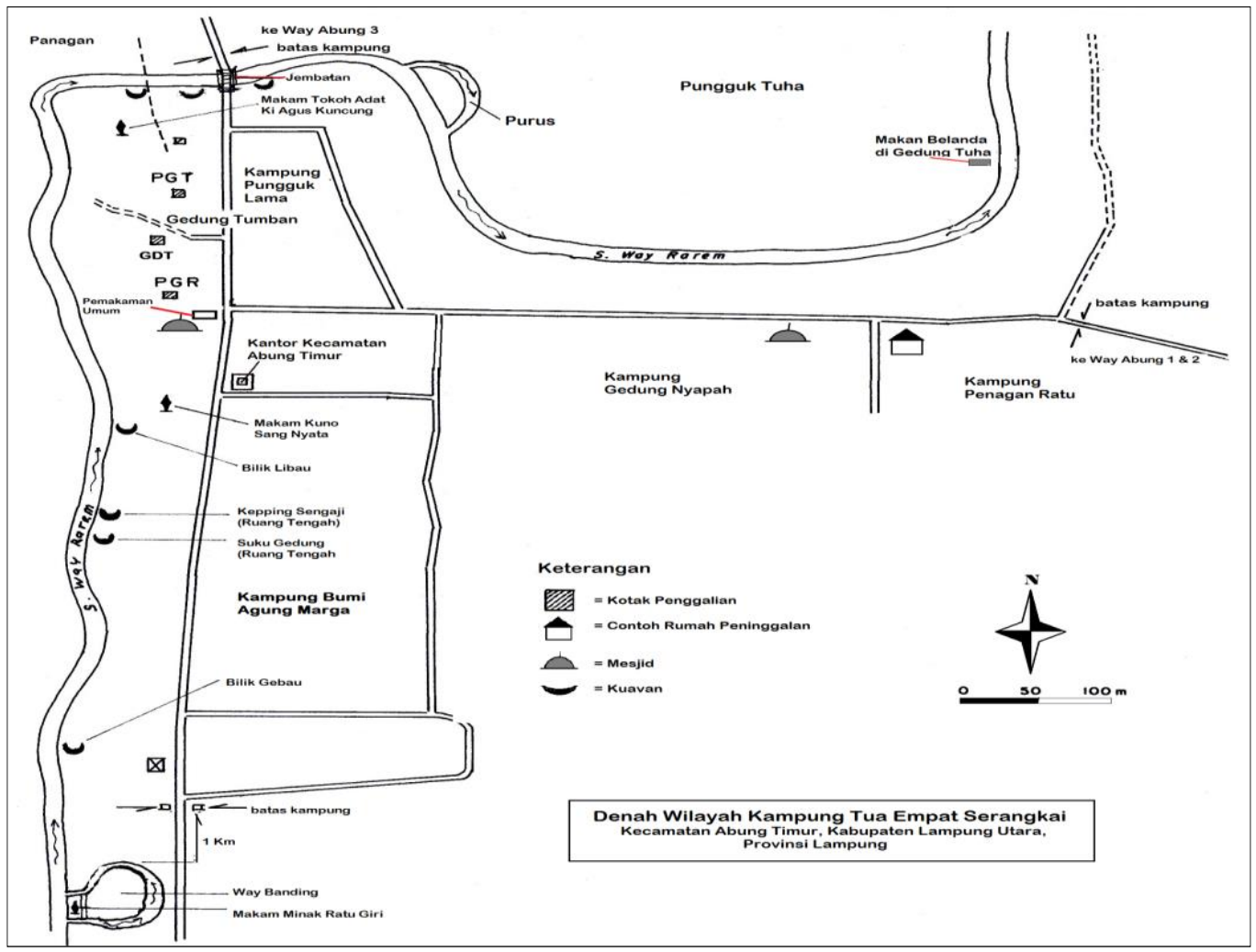

Sumber: Tim Penyusun, 2012

Nuban, Marga Buay Bulan (kedudukannya diganti Buay Nyerupa), Marga Beliyuk, Marga Selagai, Marga Buay Kunang dan Marga Anak Tuha.

Kampung Gedung Nyapah secara geografis pada koordinat $04^{\circ} 45^{\prime} 15,0^{\prime \prime}$ LS dan 104 ${ }^{\circ} 56^{\prime} 15,2^{\prime \prime}$ BT. Kampung ini memiliki batas-batas wilayah sebagai berikut: (1) sebelah utara dengan Gedung Jaya, (2) sebelah selatan dengan Gedung Harapan, (3) sebelah barat dengan Pungguk Lama, dan (4) sebelah timur dengan Penagan Ratu.

Penduduk asli kampung Gedung Nyapah berasal dari keturunan anak ke-3 Minak Pulun Brajo Tua, dan satu lagi yang tidak diketahui namanya. Kemudian menurunkan 3 orang anak, yaitu Minak Senagan Agung, Minak Brajo Musuh, dan Minak Sengaji Kilin. Warga Kampung

Gedung Nyapah terdiri dari 3 suku adat, yaitu: Bilik Gabou (keturunan Minak Senagan Agung), Ruang Tengah (keturunan Minak Braja Musuh), dan Bilik Libou (keturunan Minak Sengaji Kilin). ${ }^{4}$

Pungguk Lama $^{5}$ berasal dari kata mungguk yang berarti bukit kecil atau tanah yang lebih tinggi dari daerah sekitarnya, sedangkan kata lama berarti tua. Letak secara geografis pada koordinat $04^{\circ} 45^{\prime} 08,1^{\prime \prime} \mathrm{LS}$ dan $104^{\circ} 56^{\prime} 04,7^{\prime \prime} \mathrm{BT}$. Kampung ini memiliki batas-batas wilayah desa sebagai berikut: (1) sebelah utara dengan Papan Rejo, (2) sebelah selatan dengan Bumi Agung Marga, (3) sebelah barat dengan Margo Rejo, dan (4) sebelah timur dengan Gedung Nyapah.

Nama Pungguk Lama awalnya bernama Punggguk Tuha (tuhou), artinya Pungguk Tua atau Pungguk Lama. Sampai

${ }^{4}$ Berdasarkan informasi dari Ketua adat Kampung Gedung Nyapah sekarang, Bapak Indra Jaelani gelar Sutan Guna Marga.

${ }^{5}$ Menurut keterangan Ketua Adat Pungguk Lama, Bapak Ibnu Hajar gelar Sumbahan Ratu Anom. 
sekarang bernama Pungguk Lama. Penduduk asli Pungguk Lama berasal dari Cangok (si Bandar Putih), menyebar ke Bojong Penagan terus berjalan mengikuti aliran Sungai Way Rarem. Mereka adalah tiga bersaudara, keturunannya mendiami Pungguk, Gedung, dan Penagan.

Kampung Tua sebagai bagian dari wilayah Lampung secara umum, terlebih dahulu telah mendapat pengaruh budaya lokal lainnya yang ada di Indonesia, sebelum kedatangan Belanda. Lampung pernah menjadi wilayah kekuasaan Kerajaan Tarumanagara dan Kerajaan Sunda sampai abad ke-16 M (Guillot, 1990: 19). Ketika Kerajaan Sunda ditaklukkan Kesultanan Banten, Lampung pun menjadi daerah kekuasaannya.Akan tetapi, Kesultanan Banten (ketika itu Sultan Hasanuddin) tidak mutlak berkuasa di Lampung, terjalin hubungan simbiosis mutualistis antara kedua belah pihak. Pada tahun 1834, Belanda berhasil berkuasa di Lampung setelah beberapa kali mengalami kegagalan dalam ekspedisi kolonialisnya. Ketika itu Lampung di bawah kekuasaan Radin Imba Kusuma (Radin Inten II) (Nuralia, 2014: 136-137, Tim Penyusun, 2012: 155-156; Imadudin, 2017: 358).

\section{Permukiman Kampung Tua}

Kampung Tua memiliki topografi yang tidak rata. Secara umum kampung ini memiliki kesamaan dengan kawasan Lampung Utara, yang sebagian besar permukaan tanahnya berupa pedataran. Sebelah barat merupakan daerah perbukitan dengan ketinggian antara 450$1500 \mathrm{~m}$ dari permukaan laut. Pada bagian timur merupakan dataran rendah. Sungai yang mengalir di daerah Lampung Utara adalah Way Rarem dan Way Abung (Monografi Kec. Abung Timur, 2006).

Permukiman di Kampung Tua Empat Serangkai disebut tiyuh ${ }^{6}$, berorientasi pada sepanjang jalan utama. Setiap tiyuh terbagi lagi ke dalam beberapa

\footnotetext{
${ }^{6}$ Tiyuh digunakan masyarakat Lampung untuk menyebut perkampungan. Nama lain dari tiyuh adalah anek atau pekon (Saptono, 2014: 67)
}

bagian yang disebut bilik, yaitu tempat berdiam buay. Beberapa buay membentuk kesatuan teritorial genealogis yang disebut marga. Dalam setiap bilik terdapat sebuah rumah klan besar sebagi kerabat tertua yang mewarisi kekuasaan memimpin keluarga dan tanah milik keluarga (Saptono, 2014: 67). Keturunan pertama berhak mewarisi Sessat. Sessat merupakan rumah adat Lampung, juga tempat berunding ketika upacara adat Begawi.

Rumah tinggal penduduk kampung tua mengikuti alur tepian sungai Way Rarem. Polanya mengelompok memanjang sepanjang aliran sungai, berhadapan satu sama lain dengan membentuk jalur jalan di depan rumah-rumah berjejer memanjang. Pemukiman terbagi menjadi dua bagian jajaran rumah dengan arah hadap yang bertolak belakang antar kedua barisan. Barisan pertama adalah rumah-rumah yang menghadap ke sungai, sedangkan barisan kedua membelakangi sungai. Keadaan ini tampak di Gedung Nyapah, Penagan Ratu, dan Bumi Agung Marga. Kampung Pungguk Lama memiliki tata letak rumah membelah aliran Way Rarem, samping rumah sejajar aliran sungai (Tim Penyusun, 2012).

Perpotongan jalan sebagai penghubung antara Gedung Nyapah dan Penagan Ratu dengan Bumi Agung Marga dan Pungguk Lama. Di antaranya berdiri rumah-rumah saling berhadapan dan berseberangan. Beberapa rumah tinggal di Bumi Agung Marga, Gedung Nyapah, dan Penagan Ratu dengan posisi samping rumah menghadap sungai, seperti di Pungguk Lama (Tim Penyusun, 2012).

Bangunan rumah tua sebagai pola permukiman tingkat mikro dipengaruhi beberapa faktor, yaitu berkaitan dengan mata pencaharian, bahan bangunan, lingkungan, keterampilan dan teknologi, struktur keluarga, kekayaan, dan status sosial (Mundardjito, 1990: 21-22). Rumah hunian/tinggal di Kampung Tua adalah permukiman tingkat mikro, sedangkan wilayah Kampung Tua adalah tingkat semi 
mikro. $^{7}$ Permukiman merupakan suatu kawasan terdiri dari beberapa unsur pembentuknya, menjadi indikasi adanya wilayah hunian di masa lalu, seperti: rumah tinggal, kantor, pasar, kebun/ladang, WC umum, pemakaman umum, sarana dan prasarana transportasi (jalan, jembatan, sungai), rumah ibadah, dan lain-lain.

\section{Akulturasi Budaya}

Wujud akulturasi dalam budaya nonfisik, salah satunya dalam sistem adat lama yang telah mengalami sedikit pergeseran nilai-nilai dan penampakan penyelenggaraannya. Masyarakat adat Lampung secara umum terbagi dua sistem adat adat lama, yaitu Lampung Pepadun ${ }^{8}$ dan Lampung Sebatin atau adat Peminggir. Daerah adat Pepadun berada di Kota Tanjungkarang sampai Giham (Belambangan Umpu), Way Kanan sampai Bukit Barisan sebelah barat. Sementara itu, daerah adat Sebatin ada di sepanjang pantai selatan hingga ke barat dan ke utara sampai ke Way Komering.

Sistem adat Pepadun terbentuk sekitar abad ke-17 oleh empat kebuayan, yaitu Buay Unyai di Sungai Abung, Buay Unyi di Gunung Sugih, Buay Uban di Sungai Batanghari dan Buay Ubin (Subing) di Sungai Terbangi, Labuhan Maringgai. Keempat buay merupakan utusan masing-masing wilayah yang

\footnotetext{
${ }^{7}$ Ada tiga tingkatan Pola persebaran dan hubungan dalam permukiman, yaitu: (1) tingkat mikro (individual buildings), mempelajari hubungan antar ruang dalam satu unit bangunan; (2) tingkat semi mikro (community layouts), mempelajari hubungan antar unit ruang dalam satu komunitas (situs); dan (3) tingkat makro (zonal pattern), mempelajari hubungan antar situs yang meliputi beberapa komunitas (Clarke, 1977: 23) (Nuralia, 2014: 135-136)

${ }^{8}$ Pepadun adalah satu benda dari bahan kayu yang dipahami sebagai tahta kerajaan atau kursi tempat duduk raja atau penguasa pada zaman dahulu (Wawancara dengan tokoh adat Kampung Tua, 2012)
}

membentuk rapat adat. Keempat kebuayan tersebut sama-sama tertarik kepada Putri Bulan dari Banten, sehingga rapat adat ditunda karena terjadi keributan di antara mereka. Untuk menyelesaikan masalah tersebut diadakan musyawarah untuk mufakat dengan keputusan bahwa Putri Bulan diangkat menjadi saudara oleh keempat kebuayan tersebut. ${ }^{9}$

Masyarakat beradat Pepadun tidak mengenal kelas sosial. Penggantian Ketua Adat/Punyimbang Adat dapat dilakukan kapan saja dan diganti oleh siapa saja, dengan syarat-syarat yang telah ditentukan. Diperkirakan yang pertama kali mendirikan adat Pepadun adalah masyarakat Abung sekitar abad ke-17 M di zaman seba Banten. Pada masa ini telah terjadi pencampuran dua budaya, Lampung dan Banten. Keduanya saling bersinergi sehingga menghasilkan sistem nilai yang baru, lebih demokratis dalam memilih ketua adat. Kemudian di abad ke-18 M, adat Pepadun berkembang di daerah Way Kanan/Buai Lima, Tulang Bawang/Empat Marga, Sungkai/Negeri Ujung Karang, Way Seputih (Pubian Telu Suku), dan Abung Siwo Mego (Abung 9 marga).

Perkembangan terus terjadi seiring dengan masuknya nilai-nilai baru dari luar (budaya asing), terutama setelah masuknya Belanda dengan budaya Baratnya. Pada permulaan abad ke-19 M, adat Pepadun disempurnakan dengan masyarakat kebuayan inti dan kebuayan-kebuayan gabungan, sebagai berikut.

1. Abung Siwo Mego (Unyai, Unyi, Subing, Uban, Anak Tuha, Kunang, Beliyuk,Selagai,Nyerupa). Masyarakat Abung mendiami 7 wilayah adat: Kotabumi, Seputih Timur, Sukadana, Labuhan Maringgai, Jabung, Gunung Sugih, dan Terbanggi;

2. Mego Pak Tulangbawang (Puyang Umpu, Puyang Bulan, Puyang Aji, Puyang Tegamoan). Mendiami 4

\footnotetext{
${ }^{9}$ Menurut cerita masyarakat setempat, sebagaimana disampaikan Bapak Khoiri.
} 
wilayah adat: Menggala, Mesuji, Panaragan, dan Wiralaga;

3. Pubian Telu Suku (Minak Patih Tuha, Minak Demang Lanca atau Suku Tambapupus, Minak Handak, Hulu/Suku Bukujadi). Masyarakat Pubian mendiami 8 wilayah adat: Tanjungkarang, Balau, Bukujadi, Tegineneng, Seputih Barat, Padang Ratu, Gedungtataan, dan Pugung Sungkay-Way Kanan Buay Lima (Pemuka, Bahuga, Semenguk, Baradatu, Barasakti/lima keturunan Raja Tijang Jungur); dan

4. Sungkay-Way Kanan mendiami 9 wilayah adat: Negeri Besar, Ketapang, Pakuan Ratu, Sungkay, Bunga Mayang, Belambangan Umpu, Baradatu, Bahuga, dan Kasui.

Masyarakat adat Lampung Sebatin mengenal golongan/kelas sosial. Ketua adat Punyimbang Adat Sebatin diangkat secara turun temurun (genealogis). Masyarakat beradat Sebatin mendiami 11 wilayah adat, yaitu: Kalianda, Teluk Betung, Padang Cermin, Cukuh Balak, Way Lima, Talang Padang, Kota Agung, Semaka, Belalau, Liwa, dan Ranau, sebagian komering, serta sebagian Banten (Cikoneng). Masyarakat adat Sebatin atau Peming gir terdiri dari: (1) Peming ir Paksi Pak (Buay Belunguh, Buay Pernong, Buay Nyerupa, Buay Lapah di Way); dan (2) Komering-Kayuagung, sekarang termasuk Provinsi Sumatera Selatan.

Masyarakat adat Sebatin adalah masyarakat adat yang menganut adat tidak Pepadun, yakni melaksanakan adat musyawarah tanpa menggunakan kursi Pepadun. Sebagian besar berdiam di tepi pantai, disebut juga adat Pesisir. Masyarakat adat Peminggir sukar untuk diperinci karena di setiap daerah kesebatinan terlalu banyak asal keturunannya, terdiri atas: Masyarakat adat Peminggir, Melinting Rajabasa, Peminggir Teluk, Peminggir Semangka, Peminggir Skala Brak, dan Peminggir Komering.

Kedua sistem adat lama sampai sekarang masih bertahan dengan sifatnya masing-masing. Dalam hal ini telah terjadi masyarakat adat ganda yang berjalan beriringan dalam satu masa dan wilayah yang sama. Dengan demikian, akulturasi terjadi dengan tidak menghilangkan budaya asli. Substansi adat pun masih seperti aslinya, walau dalam pelaksanaan ada beberapa perubahan disesuaikan dengan perkembangan zaman.

Manusia ditandai dengan peran historisitasnya, yaitu sebagai subjek sekaligus objek sejarah. Dalam suatu lingkaran sejarah akan terjadi pergulatan batin berwujud inovasi-inovasi kreatif. Ini adalah ciri historisitas yang melekat pada individu dan kelompok. Rekaman sejarah dengan sendirinya akan mengabadikan kontinuitas perkembangan peradaban, dan akar tradisi yang mengandung nilai-nilai menunjukkan identitas kolektif suatu masyarakat (Heidegger, 1974: 183-189). Akar tradisi masyarakat Kampung Tua telah dikemas dalam satu nilai-nilai kehidupan lama. Salah satunya dalam penyelenggaraan upacara adat Begawi.

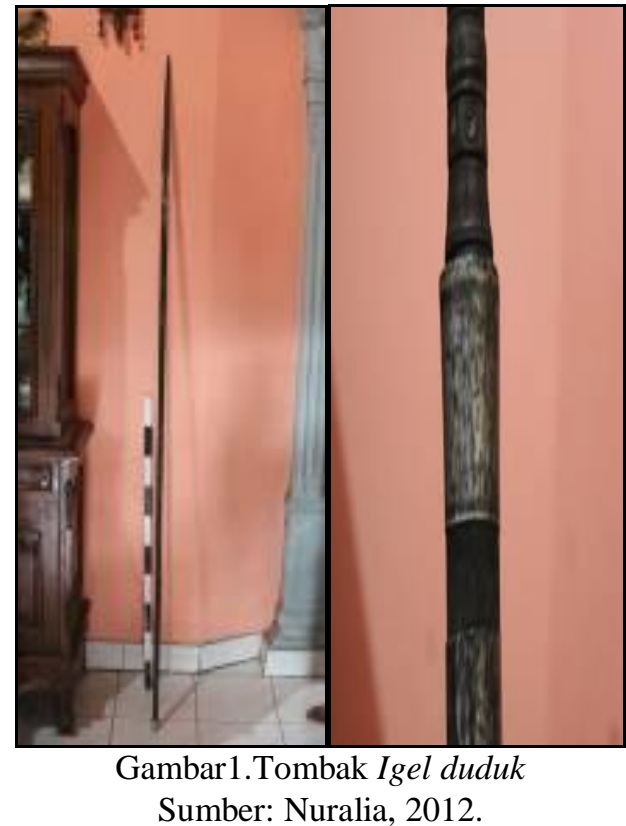

Pada penyelenggaraan upacara adat Begawi, ada banyak instrumen yang digunakan. Di antaranya benda-benda pusaka atau barang-barang peninggalan. 
Beberapa benda pusaka menunjukkan bentuk khas budaya setempat yang telah mendapat pengaruh dari luar.

Salah satu benda pusaka berupa tombak Igel Duduk (foto 1). Tombak tersebut diduga senjata yang menewaskan Minak Indah, Pepadun Tua Bumi Agung Marga. Kemudian ada beberapa benda yang dianggap memiliki nilai tinggi bagi pemilik/pemegangnya, yaitu cepuk, piring, dan buli-buli keramik (foto 5), serta peralatan dari perunggu (foto 3). Bendabenda ini disimpan Bapak Syamsudin (ketua adat Pungguk Lama) di rumahnya.

Gambar 2. Patung Burung Garuda dan peralatan dari perunggu

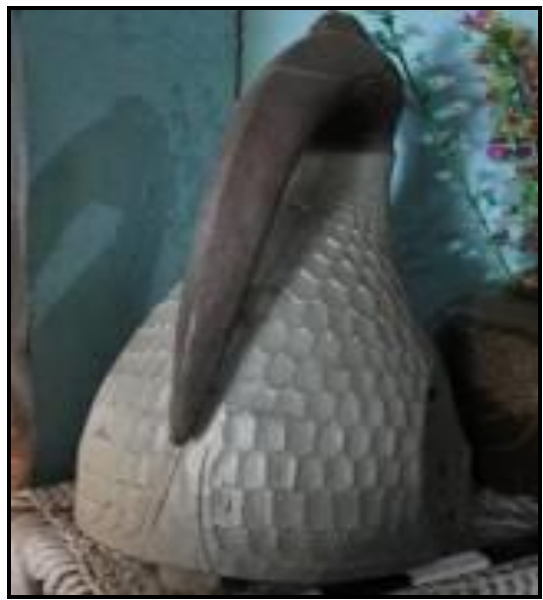

Sumber: Nuralia, 2012.

Benda untuk upacara adat kebumian yang memiliki nilai penting, yaitu patung burung garuda (foto 2), sebagai lambang kebesaran dan ketinggian cita-cita. Patung tersebut disimpan di rumah Bapak Naria di Gedung Agung. Menurutnya, patung tersebut adalah milik Sutan Ratu Tunggal (suku Ruang Tengah Bumi Agung Marga). Dahulu ada juga benda peninggalan lain, tombak jalang bekisar dan talo mulih agung (semacam gong kecil tidak diketahui keberadaannya. Benda-benda peninggalan yang masih ada adalah tempayan, guci, buli-buli, mangkok besar (pasu) dari keramik (foto 4).
Benda-benda upacara lainnya tersimpan di rumah Bapak Syamsudin, terbuat dari perunggu, yaitu pekinangan (tempat sirih) dan nampan berkaki (wadah hidangan untuk tamu). Kemudian yang disimpan di rumah Bapak fauzi, yaitu Maduari, kain penutup kepala pengantin wanita; dan Kekat Akin,penutup kepala
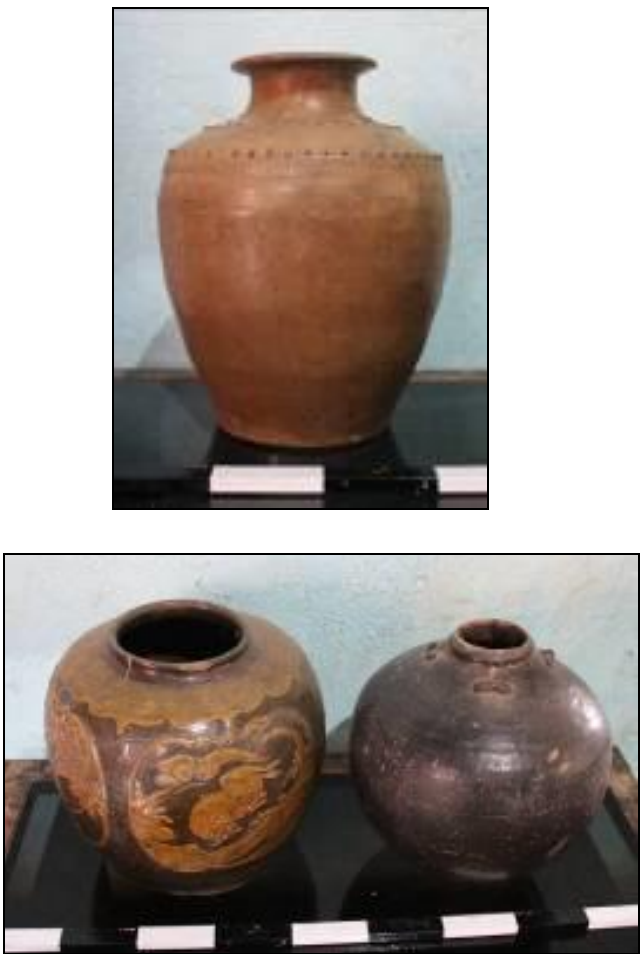

Gambar 3. Mangkuk, Guci, dan Tempayan Sumber: Nuralia, 2012

pengantin pria. Sementara itu, benda pusaka milik Bumi Agung Marga adalah tombak Jalang Bekisar, terbuat dari besi, sangat dikeramatkan, sehingga tidak dapat diperlihatkan kepada siapa pun. Tombak ini milik Minak Patih Ngesiso, pernah digunakan ketika perang dengan orang Terbanggi dari Gunung Sugih. Makamnya dapat ditemukan di Anek Banding (Umbul Banding), umbulan Bumi Agung Marga.

Berdasarkan bentuk fisik beberapa benda pusaka, tampak sudah mendapat sentuhan budaya luar. Seperti patung burung garuda dengan bentuk yang sudah dimodifikasi. Kemudian beberapa benda keramik dan gerabah, dilihat dari bentuk, 
bahan glasir, ragam hias, dan warna terang pada bagian badan, menunjukkan adanya unsur-unsur budaya luar (Jawa, Cina, Eropa). Demikian juga dengan peralatan perunggu, biasa ditemukan di wilayah budaya Jawa dan sekitarnya.

Salah satu pengaruh budaya campuran pada masyarakat Kampung dapat diamati dari segi arsitektur bangunan. Rumah adat Kampung Tua memiliki arsitektur tradisional khas, gaya campuran antara Lampung dan Banten, serta unsur-unsur arsitektur Eropa (Nuralia, 2014: 137-138).

Bentuk rumah adat Kampung Tua memiliki unsur-unsur yang terdapat pada tipikal tradisi arsitektural Austronesia kuno. Beberapa prinsip tersebut, yaitu (1) struktur kotak pada tiang fondasi kayu, ditanam ke dalam tanah atau diletakkan pada permukaan tanah dengan fondasi batu, (2) lantai panggung, (3) atap miring dengan jurai diperpanjang, dan (4) bagian depan atap condong mencuat keluar (Wisman, 2009: 28). Bentuk rumah Austronesia tampak luar berbentuk struktur tegak berupa tiang kayu, lantai ditinggikan sebagai ruang keluarga, dan atap pelana

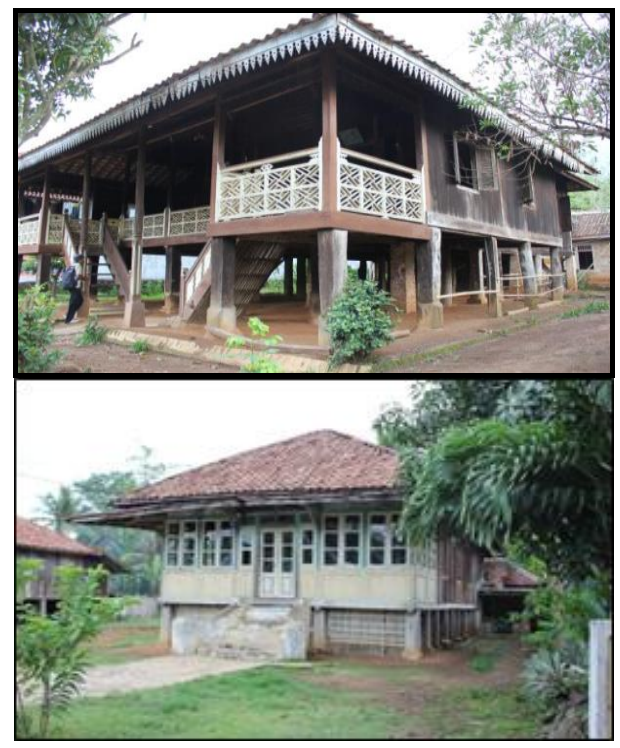

Gambar 3. Rumah panggung di Gedung Nyapah dan Penagan Ratu Sumber: Nuralia, 2012. meruncing tinggi (Sahroni, 2012).

Rumah panggung Kampung Tua (gambar3) telah mengalami pergeseran dari segi bahan bangunan dan ornamennya. Pada bagian tiang penyangga bangunan aslinya terbuat dari bahan kayu, setelah mendapat pengaruh Belanda memakai tembok beton. Beberapa hiasan atau ornament tidak lagi mencirikan secara utuh budaya Lampung. Ukiran-ukiran flora dan fauna telah menjadi ukiran geometris (kubus, lingkaran, belah ketupat, dan lain sebagainya), dan ada sentuhan modern dengan pemakaian list horizontal dan vertikal pada daun pintu dan jendela, sebagai hasil pengaruh budaya Barat. Selain itu, rumah adat Sessat di desa-desa dibangun tidak bertiang/tidak ditinggikan dari permukaan tanah, tetapi sejajar dengan permukaan tanah (depok) atau berlantai keramik (Tim Penyusun, 2012).

Bervariasinya bentuk dan ukuran rumah menunjukkan tingkat sosial ekonomi pemilik dan atau penghuninya (Nuralia, 2014: 146). Juga mencerminkan keadaan sosial ekonomi masyarakat secara umum. Keragaman juga disebabkan adanya pengaruh budaya luar, baik yang dibawa kaum pendatang maupun penduduk setempat yang kembali dari perantauan. Beberapa model rumah zaman dahulu ada yang masih mempunyai karakteristik khas, yaitu berbentuk rumah panggung bertiang sebagai rumah besar (nowou). ${ }^{10}$ Sebagai tempat tinggal, bentuk rumah penduduk asli Kampung Tua memiliki persamaan dengan rumah-rumah adat di wilayah Provinsi Lampung umumnya. Sekarang ini nowou-nowou telah banyak mengalami perubahan, mulai dari bentuk bangunan yang berlantai tanah, sampai jenis hiasan rumah tidak lagi sepenuhnya bercirikan

\footnotetext{
${ }^{10}$ Satu kampung dibagi menjadi beberapa bilik, tempat kediaman suku. Di setiap bilik terdapat rumah besar disebut nowou balak atau nowou menyanak, dan rumah-rumah keluarga lainnya. Dalam perkembangannya, di dalam satu tiyuhakan terdapat rumah kerabat tertua dan rumah-rumah kerabat baru, yang merupakan pecahan dari rumah tua (Saptono, 2014: 67)
} 
kultur masyarakat Lampung. Hal ini diperkirakan disebabkan pengaruh seni bangunan rumah yang terus berkembang, juga seiring keadaan masyarakat Lampung yang semakin majemuk.

\section{Dualisme Ekonomi Masyarakat Kampung Tua}

Secara umum sistem mata pencaharian masyarakat Kampung Tua adalah berladang, dengan sistem nomaden. Masyarakat membuka hutan kemudian ditanami padi, kopi, lada, cengkeh, dan palawija. Wilayah khusus untuk berladang disebut wilayah umbulan (Hadikusuma, 1977/1978: 71-72).

Pembukaan setiap Umbulan untuk satu Kebuayan atau keturunan pembuka Umbulan. Pembukaan Umbulan menurut hukum adat dilakukan dengan sistem magih, yaitu pertama-tama menentukan dahulu titik pusat Umbulan ditandai dengan adanya pohon besar (metro atau kemelunggung). ${ }^{11} \quad$ Upacara pembukaan Umbulan disebut Bebalay, membersihkan hutan dengan dibakar untuk berladang. Prosesi Bebalayada beberapa tahap, yaitu: (1) bikin Satin, menyiapkan sajian beras ketan, gula merah, gula putih, dan kelapa kepada pemilik sebelumnya; (2) membakar menyan; (3) membacakan doa dipimpin tokoh adat; dan (4) Tebas,membersihkan hutan untuk persiapan lahan garapan.

Wilayah Umbulan terpisah dan terletak jauh dari pemukiman penduduk atau daerah induk, berupa hamparan kebun dan ladang, yang digarap secara bersama dan kekeluargaan. Misalnya Penagan Ratu memiliki Umbulan di Derwati dan Penagan Jaya, dengan penduduk sekitar $3000 \mathrm{KK}$, sedangkan di daerah induk hanya $800 \mathrm{KK}$. Di wilayah ini ditanam tebu, karet, kelapa sawit, dan singkong. Wilayah Umbulan Gedung Nyapah adalah Gedung Jaya dan Gedung Harapan. Umbulan Kampung Bumi Agung Marga berada di Anek Banding, yang juga sebagai

\footnotetext{
${ }^{11}$ Keterangan diperoleh dari hasil wawancara dengan beberapa tokoh adat setempat (2012).
}

lokasi pemakaman umum Bumi Agung Marga. Sesuai nama wilayahnya sehingga dinamakan Umbulan Banding, berupa kebun/ladang pohon karet. Di area kebun karet ini juga ditemukan gundukan tanah tampak berbentuk melingkar, diduga sebagai benteng tanah seperti bentuk parit, yang berada di ujung area Umbulan di tepi sungai Way Banding.

Beberapa Umbulan Pungguk Lama, yaitu (1) Umbul Purus ditanami padi huma dan palawija, di seberang Way Rarem. Dahulunya merupakan umbulan paling awal milik masyarakat Kampung Pungguk Lama, (2) Umbul Semuli Karimengan ditanami kopi, lada, padi huma, karet, singkong,dan lain-lain, (3) Umbul Buluh ditanami karet, lada, padi huma, palawija, dan lain-lain. Salah satu tokoh Umbul Purus adalah Sepulau Rayo, tokoh Umbul Semuli Karimengan adalah Selibar Jagat, sedangkan tokoh Umbul Buluh adalah Waras gelar Tegi Neneng.

Di wilayah Umbulan siapa saja bisa bermukim untuk sementara sambil mengerjakan ladang mereka, baik penduduk asli maupun kaum pendatang. Bagi kaum pendatang berhak berdiam dan berladang di wilayah Umbulan apabila sudah masuk ke dalam adat dengan melakukan upacara adat, sehingga menjadi bagian komunitas adat setempat. Setiap Umbulan ada pemilik utama/penguasanya dinamakan pemilik/tokoh Umbul. Wilayah Umbulanyang dihuni pendatang dari negeri seberang, biasanya pendatang dari Jawa. Sebelumnya berupa wilayah hutan belantara. Penduduk asli yang bermukim di sekitar hutan, bermata pencaharian menangkap ikan dan beternak kerbau.

Luas wilayah Umbulan biasanya sekitar 4 hektar, digarap oleh beberapa orang kepala keluarga dari kampung induk. Setiap kepala keluarga boleh ikut mengusahakan Umbulan setelah mendapat izin dari tokoh Umbul. Dalam hukum adat Lampung ditetapkanjarak wilayah dalam satu Umbulan adalah radius 3 pal $( \pm 5 \mathrm{~km})$ dari pusat Umbulan. Pada tahun 2000 wilayah umbulan telah berkembang pesat 
dengan dibukanya perkebunan kelapa sawit dan karet. ${ }^{12}$

Banyaknya hasil yang diperoleh masing-masing keluarga sesuai luas tanah yang digarapnya. Bagi kaum pendatang yang sudah masuk adat masyarakat setempat, untuk menggarap Umbulan harus minta izin dahulu sebagai tatakrama adat, dengan memberi persembahan atau
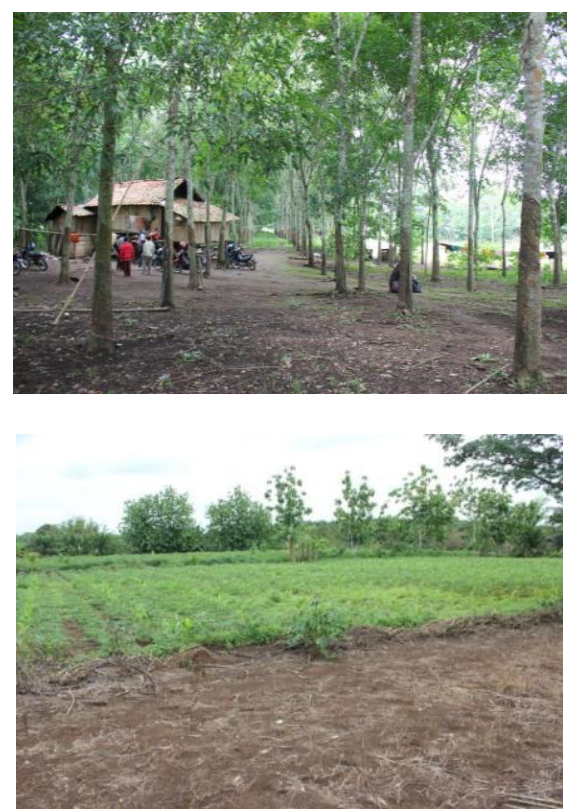

Gambar 4.Umbul Banding sebagai bekas lokasi Bumi Agung Marga tua Sumber: Nuralia, 2012

membawa barang berupa gula, beras ketan, kelapa, dan ayam. Barang-barang ini diberikan kepada tokoh adat setempat. Mengenai hasil panen tidak ada pembagian khusus dan tidak ada keharusan untuk dibagi dengan kampung induk, tetapi ada tatakrama berdasarkan kesepakatan.

Berladang dibarengi beternak kerbau serta mencari ikan di sungai Way Rarem, mata pencaharian utama masyarakat adat Kampung Tua. Masyarakat Lampung zaman dahulu, memiliki sistem mata pencaharian sebagaimana masyarakat agraris umumnya, yaitu mencari ikan,

\footnotetext{
${ }^{12}$ Menurut keterangan Kasie Pemerintahan Kecamatan Abung Timur, Aswan, 2012.
}

beternak, dan berladang. Mata pencaharian tersebut merupakan sistem ekonomi tradisional sebagai ekonomi subsitensi. Sistem ekonomi adalah suatu sistem yang mengatur dan menjalin hubungan ekonomi antarmanusia, dengan seperangkat kelembagaan. Sistem ekonomi tidak berdiri sendiri, berkaitan dengan falsafah, pandangan dan pola hidup masyarakat

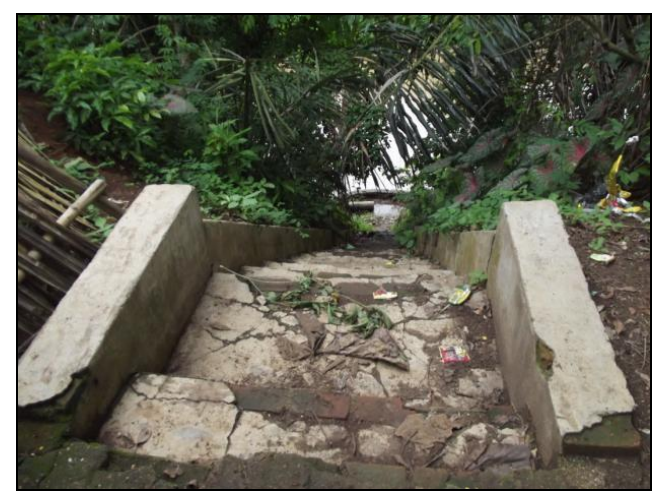

Gambar 5. Bekas Lokasi KuwayanSuku Ruang Tengah Bumi Agung Marga Sumber: Nuralia, 2012

setempat, sebagai bagian kesatuan ideologi kehidupan masyarakatsuatu negara (Dumairy, 1966), atau suatu komunitas adat tertentu di wilayah tertentu pula.

Selain keberadaan umbulan yang menjadi ciri khas perekonomian tradisional masyarakat Kampung Tua, adalah lokasi kuwayan. Kuwayan adalah satu bangunan kecil berdinding dan berlantai papan kayu, berada mengapung para permukaan air.

Bangunan kecil sederhana berdiri di lokasi landai di tepian sungai Way Rarem, berfungsi sebagai tempat bersihbersih (mandi dan cuci), disebut dengan istilah masyarakat setempat kuwayan. Biasanya dibuat dari susunan bambu sebagai dinding penghalang (bilik), menyerupai kamar mandi terbuka tanpa atap dan mengapung di atas permukaan air. Bilik bambu ini ditambatkan ke tanah, seperti rakit. Setiap suku di Kampung Tua memiliki satu kuwayan atau lebih tergantung kebutuhan. 
Kuwayan ditempatkan di tepi sungai yang landai. Untuk mencapainya dibuat tangga menurun sampai ke tanah datar. Masyarakat Kampung Tua zaman dahulu memanfaatkan lokasi landai kuwayan sebagai prasarana transportasi air untuk menambatkan perahu. Perahu yang dipergunakan berupa perahu lesung terbuat dari batang pohon Leban. Jalur air sangat mendukung aktivitas perdagangan, sehingga kuwayan tersebut dimanfaatkan juga sebagai tempat transaksi perdagangan masyarakat lokal dengan wilayah luar. Sistem peradangannya dengan cara barter. Masyarakat lokal menukar hasil bumi

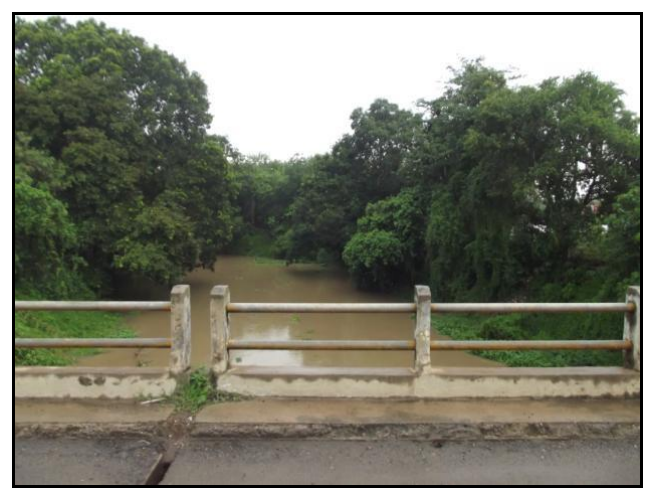

Gambar 6. Bekas lokasi kuwayan masyarakat Kampung Pungguk Lama

Sumber: Nuralia, 2012

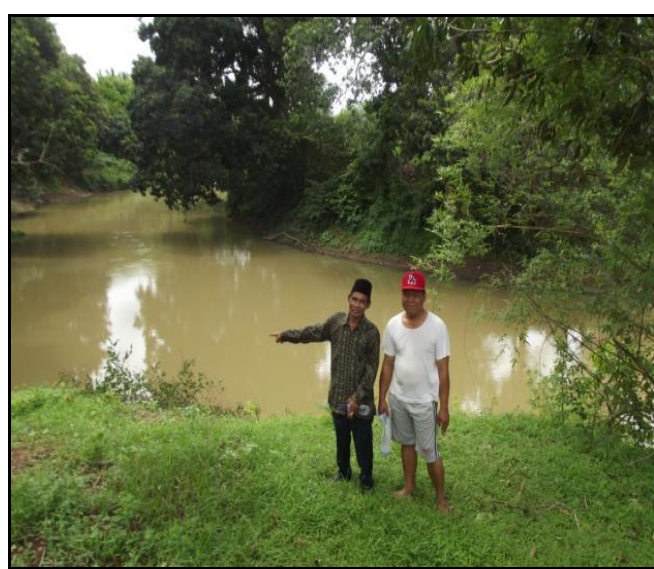

Foto 7.Bekas lokasi kuwayan di Gedung Tuha Penagan Ratu

Sumber: Nuralia, 2012.

berupa padi, ikan, kopi, karet dan palawija dengan barang kebutuhan lain berupa guci, piring, mangkok keramik atau tembikar.
Para pedagang yang singgah di kuwayan berasal dari Bugis, Palembang, Kotabumi, dan Meranjat. ${ }^{13}$ Kuwayan sebagai tempat perdagangan juga didukung data sebaran artefak, berupa fragmen keramik yang cukup melimpah, yang diperkirakan berasal dari Cina, Thailand, Vietnam, dan Eropa.

Beberapa lokasi kuwayan masih dapat dijumpai di Kampung Pungguk Lama dan Kampung Bumi Agung Marga, serta di Gedung Tuha Kampung Penagan Ratu. Bekas lokasi kuwayan di Kampung Bumi Agung Marga, yaitu (1) Kuwayan Suku Ruang Tengah, (2) kuwayan

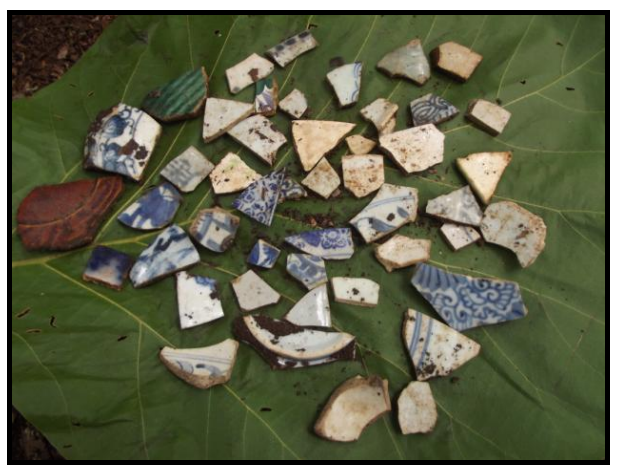

Gambar 8. Fragmen keramik di sekitar bekas lokasi kuwayanBumi Agung Marga Sumber: Nuralia, 2012.

Kampung Sengaji Suku Ruang Tengah, (3) Kuwayan Suku Bilik Libau (Minak Sang Nyata), (4) Kuwayan Suku Bilik Gabau. Di sekitar lokasi bekas kuwayan ini ditemukan beberapa fragmen keramik di permukaan tanah. Bekas lokasi kuwayan di Kampung Pungguk Lama tampak dari atas jembatan Way Rarem, menghubungkan Kampung Pungguk Lama dengan Umbulan Purus dan Umbulan Penagan di seberang sungai. Dahulunya di umbulan ini adalah bekas wilayah Kampung Pungguk Tuha sebelum pindah ke lokasi Pungguk Lama sekarang. Ada 3 bekas lokasi kuwayan di Kampung Pungguk Lama, yaitu (1) Kuwayan Rajo Muda, (2) Kuwayan Kanal,

\footnotetext{
${ }^{13}$ Seperti yang dikemukakan Bapak Saleh, tokoh adat Gedung Nyapah (2012).
} 
dan (3) Kuwayan Pasar, tetapi tidak ada sisa-sisa kuwayan yang dapat dilihat sekarang. Kemudian bekas lokasi kuwayan di gedung Tuho (Kampung Penagan Ratu) ada 3 titik, tetapi tidak diketahui apa nama kuwayan dan juga tidak ditemukan bekasnya

Peran penting lokasi kuwayan menghilang seiring masuknya Belanda ke Kampung Tua, sedangkan umbulan masih bertahan. Sistem perdagangan barter tidak dilakukan lagi digantikan dengan ekonomi uang. Profesi baru muncul ${ }^{14}$, seperti penjual jasa penyewaan alat-alat upacara adat, atau bekerja menjadi buruh/kuli di kota. Sistem ekonomi tradisional umbulan berhadapan dengan sistem ekonomi modern yang berpusat di kota kecamatan, memberi imbas ke wilayah Kampung Tua dengan munculnya beragam profesi baru. Perekenomian masyarakat Kampung Tua berkembang ke dua arah berlawanan atau perekonomian masyarakat ganda (Barat dan Timur) menjelma sebagai kelompok masyarakat didominasi ekonomi kapitalis (Barat), ekonomi kapitalis/sosialis, atau hubungan antara dua sistem sosial Barat dan Timur (Sayogoyo, 1982: 2-3). Keadaan ini menyebabkan terjadinya sistem ekonomi dualistis.

Munculnya pekerjaan baru sebagai pegawai pemerintah atau buruh/kuli di perkotaan, serta jasa ${ }^{15}$ menjadi profesi baru yang digemari sebagian penduduk Kampung Tua. Kemunculan profesi baru tersebut terutama terjadi pada masa Pemerintahan Belanda. Pada saat Belanda berkuasa di Lampung, termasuk Kampung Tua, sebagian penduduk kampung migrasi ke kota dalam rangka mencari kerja atau penghasilan tambahan. Kondisi ini menunjukkan mulai bergesernya sistem ekonomi tradisional dengan distribusi barang dengan cara barter, kepada sistem

\footnotetext{
${ }^{14}$ Berdasarkan informasi dari beberapa orang ketua adat marga (wawancara, 2012).

${ }^{15}$ Ketika penelitian dilakukan di tahun 2012 penjual jasa di beberapa tempat di wilayah Kampung Tua semakin beragam.Di antaranya jasa penyewaan alat-alat upacara adat Begawi.
}

ekonomi modern dengan pertukaran uang/ekonomi uang.

Perekonomian tradisional di pedesaan yang didominasi sektor pertanian, bersifat subsistensi (memenuhi kebutuhan sendiri), dengan pertumbuhan penduduk tinggi mengakibatkan terjadi kelebihan supply tenaga kerja (Arthur Lewis dalam Mulyani, 2007). Bertambahnya jumlah penduduk Kampung Tua secara otomatis jumlah tenaga kerja semakin bertambah, sehingga ekonomi subsistensi yang terjadi Kampung Tua mengalami pergeseran.

\section{PENUTUP}

Masyarakat Kampung Tua sampai sekarang masih mempertahankan nilainilai budaya lama. Ada beberapa unsur luar yang masuk, tetapi hanya pelengkap dengan tidak menghilangkan budaya aslinya (akulturasi budaya). Unsur-unsur luar di antaranya budaya Banten dan Jawa Tengah, serta Eropa (Barat).

Wilayah Kampung Tua menjadi wilayah masyarakat adat dengan ciri khas perkampungan yang relatif masih asli. Tampak dari arsitektur rumah tinggal dan dua adat lama, pepadun dan sebatin. Juga upacara adat Begawi dalam kenaikan takhta dan perkawainan.

Satu ciri khas lainnya adalah sistem ekonomi dualistis. Ditandai dengan keberadaan umbulan dan bekas lokasi kuwayan.Wilayah umbulan sebagai kantong perekonomian tradisional masih bertahan sampai sekarang. Sementara itu, peran lokasi kuwayan sudah tergantikan dengan berkembangnya profesi baru dengan sistem ekonomi modern/uang.

\section{UCAPAN TERIMA KASIH}

Penulis mengucapkan terima kasih pada para tetua adat dan warga Kampung Tua Kecamatan Abung Timur Kabupaten Lampung Utara yang memberikan informasi lisan terkait topik penelitian ini. 


\section{DAFTAR SUMBER}

\section{Jurnal}

Humaedi, M. Alie.

"Kegagalan Akulturasi Budaya dan Isu Agama dalam Konflik

Lampung", Jurnal "Analisa"

Volume 21 Nomor 02 Desember

2014. Hlm.149-162.

Imadudin, Iim.

"Perdagangan lada di Lampung dalam Tiga Masa (1653-1930)", dalam Patanjala Vol. 8 No. 32016. Hlm. 349-364.

Irianto, Sulistyowati dan Risma Margaretha.

"Piil Pesenggiri: Modal Budaya dan Strategi Identitas Ulun Lampung", Makara, Sosial Humaniora, Vol. 15, No. 2, Desember 2011.Hlm.140150.

Poerwanto, Hari.

Asimilasi, Akulturasi,dan Integrasi

Nasional, Humaniora, No. 12

September-Desember 1999. Hlm. 29-37.

\section{Buku}

Adat, Sutan Pusetes. 1973.

Sejarah Asal Mula Adat Pepadun. Tanjung Karang.

Abdul Hakim dari Jaarboek van Batavia en Omstreken. Jakarta: Metro Pos.

Kuper, Adam. 1999.

Culture. Cambridge: Harvard University Press.

Berry, D.W. and J.L. Sam. "Acculturation and Adaptation", in J.W. Berry, M.H. Segal, C. Kagitcibasi, 1997, Handbook of Cross-cultural Psychology, Volume 3, "Social Behavior and Aplications", Boston: Allyn and Bacon. P. 291-326.

Mulyani, Endang et al. 2007.

Ekonomi Pembangunan. Jakarta: Universitas Terbuka, Copyright BMP.

Monografi, 2006.
Buku Monografi Kecamatan Abung Timur, Kabupaten Lampung Utara, Provinsi Lampung.

Boeke, J.H. 1983.

Prakapitalisme di Asia (The Interest of The Voiceless Far East, Introduction to Oriental Economics), terjemahan D. Projosiswoyo. Jakarta: Yayasan Sinar Harapan bekerja sama dengan Yayasan Tani Atsiri Wangi.

Dumairy. 1996.

Perekonomian Indonesia. Bandung: Erlangga

Geertz, Clifford. 1992.

Tafsir Kebudayaan (terjemahan dari Interpretation of Culture).

Yogyakarta: Kanisius Press.

Hadikusuma, H. Hilman. 1989. Masyarakat dan Adat Budaya Lampung. Bandung: Mandar Maju.

Hadikusuma, Hilman. 1977/1978. Adat Istiadat Daerah Lampung. Jakarta: Departemen Pendidikan dan Kebudayaan.

Handinoto. 2010. Arsitektur dan Kota-Kota di Jawa pada Masa Kolonial.Yogyakarta: Graha Ilmu.

Heidegger, Martin. 1974.

Identity and Difference. New York: Harper.

Kardiman et al. 2006.

Ekonomi Dunia Kesehatan Kita. Jakarta: Yudistira.

Kuntowijoyo. 2001.

$\begin{array}{lcc}\text { Pengantar } & \text { Ilmu } & \text { Sejarah } \\ \text { Yogyakarta: } & \text { Yayasan } & \text { Bentang } \\ \text { Budaya. } & & \end{array}$

Kuper, 1999.

Culture. Cambridge: Harvard University Press.

Mundardjito. 1990.

"Metode Penelitian Arkeologis", Lembaran Sastra II, Edisi Khusus Monumen: Karya Persembahan 
untuk Prof. Dr. R. Soekmono. Depok: Fakultas Sastra Universitas Indonesia. Hlm. 19-30.

Nuralia, Lia. 2012.

"Kearifan Lokal Masyarakat Peladang di Situs Kabuyutan Ciburuy Kabupaten Garut." Dalam Wanny Rahardjo W (Editor). Arkeologi Identitas dan Karakter Budaya dalam Kajian Arkeologi.Bandung: Al-Qaprint. Hlm. 75-94. 2014.

"Arsitektur Bangunan Rumah Adat Kampung Tua di Kecamatan Abung Timur, Lampung Utara." Dalam Kresno Yulianto (Editor), Perkembangan Permukiman di Lampung dalam Perspektif Arkeologi. Bandung: Balai Arkeologi Bandung.

O’Malley, William J. 1988.

"Perkebunan 1830-1940: Ikhtisar". Dalam Anne Booth, William J. O'Malley, Anna Weidermann (Penyunting), Sejarah Ekonomi Indonesia.Jakarta: LP3ES.

Purwanto, Hari. 2000.

Kebudayaan dan Lingkungan dalam Perspektif Antropologi. Yogyakarta: Pustaka Pelajar.

Reiner, G.J. 1997.

History Its Purpose and Methods. London: George Allen and Unwim Ltd.

Saptono, Nanang. 2014.

"Pola Perkampungan dan Mata Pencaharian Masyarakat". Dalam Kresno Yulianto (Editor), Perkembangan Permukiman di Lampung dalam Perspektif Arkeologi. Bandung: Balai Arkeologi Bandung, Kementerian Pendidikan dan Kebudayaan. Hlm. 63-78.

Sajogyo (penyunting). 1982.

Bunga Rampai Perekonomian Desa. Jakarta: Yayasan Obor Indonesia dan Yayasan Agro Ekonomika.
Sumintarja, D. 1981.

Kompendium Sejarah Arsitektur, Jilid I. Bandung: Yayasan Lembaga Penyelidikan Masalah Bangunan.

Warganegara, Marwansyah. 1994. Riwayat Orang Lampung. Jakarta.

Wisman, Jan J.J.M. 2009.

"Posisi dan Peran Tradisi-tradisi Vernakuler Indonesia dan Langgam Bangunan Masa Lalu dalam Masa Kini". Dalam Peter J.M. Nas dan Martien de Vletter (Penyunting), Masa Lalu dalam Masa Kini: Arsitektur di Indonesia. Alih Bahasa Alex TriKantjono W (dkk). Jakarta: Gramedia Pustaka Utama.

\section{Makalah}

Sahroni, Ade. 2012.

"Arsitektur Vernakular Indonesia: Peran, Fungsi, dan Pelestarian di dalam Masyarakat". Dalam Makalah PIA 2011. Jakarta: Puslitbang Arkenas 19 Maret 2012.

Tim Penyusun, 2012.

Laporan Penelitian Arkeologi, Pusat Peradaban di Kabupaten Lampung Utara, Perkembangan Hunian dan Budaya. Bandung: Kementerian Pendidikan dan Kebudayaan, Pusat Penelitian Arkeologi, Balai Arkeologi Bandung (tidak diterbitkan).

\section{Wawancara}

Aswan, di Bumi Agung Marga, 30 November 2012

Ikmidar gelar Adi Sutan, di Bumi Agung Marga, Pungguk Lama, Gedung Nyapah, Penagan Ratu, November-Desember 2012.

Khoiri Rujungan, di Kotabumi, Bumi Agung Marga, Pungguk Lama, Gedung Nyapah, Penagan Ratu, November-Desember 2012.

Syamsudin, Kotabumi, Bumi Agung Marga, Pungguk Lama, Gedung 
Nyapah, Penagan Ratu,

November-Desember 2012.

\section{Internet}

Bruno Hildebrand, Die National Ekonomie der gegenwart und Zukunfit (1848), http://www.encyclopedia. com/social-sciences/applied-andsocial-sciences-magazines/hilde brand-bruno, diakses 29 Desember 2016. 